\title{
Cultural congruency and shocking buzz campaigns: contrasting the opinions of professionals and consumers
}

\author{
Karim BEN YAHIA \\ Associate Professor, ISBAM, LARIME, karim_b_yahia@yahoo.fr \\ Soukeina TOUITI \\ PhD Student, ISG Tunis, LARIME, touiti.soukeina@yahoo.fr \\ Mourad TOUZANI \\ Associate Professor, NEOMA Business School, mourad.touzani@neoma-bs.fr
}

Received: 10 February 2015 / Revised: 9 March 2016 / Accepted: 23 March 2015 / Published online: 6 May 2016

\begin{abstract}
Buzz marketing in social networks is often seen by announcers as an opportunity to reach the biggest audience. However, the risk of failure of buzz campaigns proves not to be negligible and its consequences may be serious for the company. In order to succeed in such buzz campaigns, this research study focuses on cultural aspects, and more particularly on the central role of cultural congruency. To explore these aspects, a qualitative study, based on 36 face-to-face interviews with marketing professionals/advertisers and consumers, has been carried out. The results highlight the importance of cultural values for consumers in Arab-Muslim countries, especially when buzz marketing campaigns touch the taboos. Terms used in the advertisement are also decisive in the success of a buzz campaign.
\end{abstract}

JEL classification: M30, M31, M37, M39

Keywords: buzz, cultural congruency, values, religion, taboo.

\section{INTRODUCTION}

Nowadays, there is a stream of advertising that is nothing but a result of consumer society. This stream is increasingly perceived as a burden by consumers who are becoming either indifferent or hostile to messages that follow them everywhere they go. This is not really what advertisers expect, their objective being to capture consumers' attention and get them interested. Therefore, over time, with this relentless "hype", consumers are becoming disappointed, tired, uncaring, bored and even mistrustful toward advertising (Oosterwijk and Loeffen, 2005).

Overload is one of the reasons of the decrease of efficiency of the traditional media. Subsequently, companies are now required to innovate, find more creative and original solutions. Social networks such as Facebook, Twitter or YouTube seem to offer an ideal ground to develop new ways of communicating with consumers (Ashley and Tuten, 2015; Kozinets et al., 2011; Proulx et al., 2012). In the era of new technologies, this may lead buzz marketing to occupy 
a prominent place in the communication strategies of companies (Fournout et al., 2012; Kimmel, 2014).

A marketing campaign can fail even when managers comply carefully with the different stages of the advertising process. Today, a company has several audiences that could be characterized by huge differences, especially on the cultural level (Ersig, 2001). What a consumer can tolerate and/or accept without any problem in a given setting may seem extremely shocking to another consumer in another country. Consequently, the old debate on the choice between adaptation, standardization and median strategy (Liessem, 2015) seems also valid for a company that wants to start a buzz marketing campaign.

Prima facie, it is important to define the concept of buzz. "Buzz marketing consists of creating positive word of mouth around a product by turning selected consumers into spontaneous carriers of the message. This then spreads in concentric circles, from the trendsetters to the mainstream consumers. It is not a matter of shouting to everybody but whispering to the right people. The buzz marketing process illustrates the virus metaphor: inoculation (of a product), incubation (use of the product by the few primary inoculated consumers), spreading and infection (passing of the product). It is based on the valorization of the selected consumers, who feel proud to have a scoop" (Salzman et al., 2003, p. 5).

Buzz marketing is therefore a technique that can affect brand image and reputation (Gastal et al., 2011; Rosen, 2001). Its main purpose is to let the social system speak about a product or a service, even before its introduction into the market. It does so by creating a word-of-mouth around it via opinion leaders whose sociability and expertise significantly contribute to the diffusion of information and the influence of other consumers, who take their turn and become brand ambassadors, and so on (Stambouli and Briones, 2002). However, these relays can alter the content of the message both positively and negatively. Buzz can indeed generate positive reactions towards the brand, increase brand awareness, and improve brand image as well. Unfortunately, this is not always the case since buzz can lead to negative reactions when the company loses control over the transmission of the information especially in social networks, where videos are sometimes shared with a breathtaking velocity among an impressively large audience.

Many buzz campaigns have gone wrong and left behind the legacy that can be recovered neither in branding nor in sales (Burcher, 2012). From this perspective, culture may be an interesting angle of attack to analyze these campaigns as it allows, in our opinion, for understanding better the extent to which buzz can degenerate and become a danger to the advertiser (Ben Yahia et al., 2012).

\section{LITERATURE REVIEW}

To ensure maximum success, a buzz campaign is supposed to arouse curiosity, surprise, desire, or delight (Oosterwijk and Loeffen, 2005; Sternthal and Craig, 1973) through effects sometimes inspired from shockvertising, which seems to be a new trend in the world of communication (Dahl et al., 2003). Therefore, an advertising campaign can be considered as shocking when it presents themes that have no objective relationship with the product or the company and when it is likely to cause violent reactions from consumers (Arn, 2001).

Shock advertising pushes forward to consumers a message that they do not want and/or do not intend to be exposed to, bearing in mind that what is considered offensive to one person may not be for the other. The ultimate goal of this type of advertising is to let the audience speak about the product. But daring to challenge the values and go against what is supposed to be acceptable and tolerated by all does not come without risk (Chatterjee and Tata, 1998). Actually, shockvertising appeals to topics such as violence, drugs, death, racism, sex or religion (Severn et al., 1990; Kilicbay and Binark, 2002) in order to bring out strong feelings such as anger, revolt or grief in 
the viewer (Garcia, 2010). These feelings are supposed to ease the access to consumers' memory. However, as we mentioned earlier, agreeing to discuss shocking topics is relative and depends on the receiver of the advertisement; the same reasoning is also valid for the country or geographical area. Indeed, what is tolerated in one society is not elsewhere, because cultures differ. It is therefore necessary, especially for companies looking to target several markets, not to forget the cultural factor when developing their communication strategies (McCraken, 1986; Moriarty et al., 2014; Snyder et al., 1991). Indeed, most of the research dealing with cross-cultural advertising admits that culture is a basis for the content of advertising and other forms of communications (Al-Olayan and Karande, 2000; Galissot, 1994; Hong et al., 1987; Mueller, 1987; Tansey et al., 1990).

By analogy with advertising, buzz marketing should not turn to neglecting cultural aspects. This is the main objective of the present research since, in our knowledge, no studies have explained the contents of buzz marketing taking into consideration culture as an important feature which can guarantee the success or cause the failure of a buzz campaign. It is therefore imperative to explain the importance of culture in the development of communication strategies designed specifically to be broadcast on social networks. For that, we consider three important cultural components: values, taboos and religion.

Cultural differences can first be explained through a comparison between the value systems (Feather, 1975; Rokeach, 1973). Values can be viewed as beliefs, attitudes and activities approved in a community and reinforced by a set of rewards/punishments for those who meet/deviate from the guideline (Rokeach, 1973). Durgee et al. (1996) argue that a better understanding of consumers comes by knowing their values. On a personal level, values inspire all types of consumer behaviour (Connor and Becker, 2003; Cai and Shannon, 2012), and in particular motivations and choice (Durvasula et al., 2011), purchasing decisions (Koubaa et al., 2011) and media selection (Odin et al., 1996). Since communication messages convey values, it is often reminded that these messages should be in harmony with the prevailing beliefs of the target and operate as a "mirror that only reflects and exposes existing cultural values and behaviours" (Pollay, 1986, p. 910). However, the reality is much more complex since values are numerous, varied, inter-related, not of equal importance, and sometimes difficult to operationalize in a communication campaign, and $a$ fortiori, in a buzz campaign. Values play indeed an important role in the case of buzz marketing and may influence the perception of websites and their content (Li et al., 2009), as well as individuals' willingness to engage in an interpersonal communication process (Kropp et al., 2005). The impact may also become thorny in the case of a buzz campaign going against the target's values.

Taboos may also be an interesting window through which cultural values may be analyzed. Shocking and provocative (Lambek, 1992; Sabri, 2015; Skorupa, 2014), they are based on the social norms and the prohibitions assimilated by the group members (Freud, 1912; Durkheim, 1915; Webster, 1942; Cazeneuve, 1971). Taboos are cultural productions that use a set of stimuli liable to "shock or offend by transgressing internalised norms or by triggering emotionally ambivalent responses, such as simultaneous excitement and guilt" (Sabri, 2010). Breaking taboos may lead to internal and/or social sanctions. Accordingly, internal sanctions occur through emotions such as shame, guilt and embarrassment (Heywood, 2002).

Social sanctions consist of categorizing some individuals as marginal people, nonconformists and may cause negative social reactions resulting in their exclusion (Schachter, 1961; Schur, 1971; Earle, 1986; Marques and Paez, 1994). Taboos can appear in conversations as they deal with subjects that can hardly be addressed (Walter, 1991). They can also reveal themselves through behaviours when acts are against social norms. What is interesting for us is that the taboo may be perceived in different ways from one culture to another (Sabri and Obermillerb, 2012), which should be considered by promotion managers implementing a buzz campaign in order to avoid offending people and giving rise to negative reactions. 
It is also imperative for a company targeting an Arab-Muslim culture to take into account religion and respect for the holy (Cleveland et al., 2011; Delner, 1994; Luqmani et al., 1989). Early writings in marketing recommended advertisers to never mix religion and business (Van Dyke, 1980). Even though everywhere around the globe, people are progressively accepting the way modern advertising communicates, not all countries accept the change with the same speed and some contents may still shock some consumers (Fam et al., 2004). Multinational companies are now used to adapt their content according to the religious background of the target. For instance, people are significantly less depicted when advertising to the Arabic world (Al-Olayan and Karande, 2000) and when women appear, their bodies are more covered than in Western countries (Al-Makati et al., 1996; Luqmani et al., 1987).

Usually, advertisers and promotion managers try not to transgress values, taboos, and religious beliefs and practices. However, advertisers may sometimes adopt another strategy: try to go beyond the threshold of acceptability and reach censorship as a result but with a greater visibility. Indeed, consumers will hear about this ad through the buzz and try their best to see it by all means either in the newspapers or on the net (Garcia, 2010). In other words, scandal creates buzz; that makes it increasingly used by advertisers in recent years, especially since it is a way to increase awareness and differentiation, or to rejuvenate a brand by giving it the opportunity to speak to younger targets.

In conclusion, consumers may react differently to an advertisement according to their culture (Harris and Attour, 2003; Zhang and Gelb, 1996; Buzzell, 1986; Harris, 1984), which underlines the need to conduct prior studies to emphasize the socio-cultural specifics of the target market (Abernethy and Franke, 1996; Al-Olayan and Karande, 2000) in order to ensure the success of a buzz campaign.

\section{RESEARCH METHODOLOGY}

The objective of this research is to explore the way culture may interfere with buzz marketing practices and how marketing professionals may integrate cultural components when planning and implementing a buzz campaign. To meet this objective, a qualitative inductive research was conducted. This choice is justified by the paucity of research dealing with the perceptions of cultural elements present in advertising on social networks. Indeed, a qualitative approach is recommended when little research has been carried out concerning a topic or a setting (Morrow and Smith, 2000).

Our basic assumption is that a cultural reading of buzz campaigns would allow us to better understand how they can succeed or, on the contrary, become a danger to promotion managers. This research is an attempt to analyze, from a cultural perspective, buzz campaigns that have been massively viewed on social networks, whether they scored positively or negatively in consumers' minds. These campaigns are meant to evoke in the target audience surprise, desire, curiosity or amusement through effects sometimes inspired from shockvertising. These campaigns may respect or infringe the cultural background of the audience. Face-to-face semi-structured individual interviews with communication and promotion managers confronted with such situations have been carried out. This technique seems to be appropriate as it brings out latent elements in the mind of interviewees as well as information difficult to disclose given their "taboo" or annoying character (Flick, 2009; Alston and Bowles, 2003).

The qualitative sample of this study consists of two groups: -16 interviews with professionals working in the marketing communication agencies or digital agencies and announcers, including brand managers and marketing managers and -20 interviews with consumers who were exposed to buzz campaigns on social networks. This "triangulation of data sources" contributes to gathering different perspectives and opinions about buzz: the idea was not to gain a unique 
consistent picture of the reality, but rather to have access to varied and sometimes different perspectives (Patton, 2002). We considered it interesting to identify some points of convergence and divergence in the views of our target.

For professionals (designated by $\mathrm{P}$ in Table 1), a snowball sampling procedure was adopted where each interviewee recommended one or several other individuals from their portfolio of acquaintances. All of the selected respondents were either advertising managers operating in communication/digital agencies or professional announcers who had at least one experience of buzz. As for consumers (designated by $\mathrm{C}$ in Table 2), we selected respondents who were exposed to buzz marketing campaigns on social networks and who were ready to share with us their opinions, perceptions and attitudes about those campaigns. To avoid duplication of gathered information, we decided to put an end to the interviews when the sample size allowed us to achieve theoretical saturation (Longhofer et al., 2012; Holton, 2010; Strauss and Corbin, 1990).

Table 1

Professionals: Description of the interviewees' profile

\begin{tabular}{|c|c|c|c|c|c|}
\hline Informant & Company's name & Interviewee's profession & $\begin{array}{c}\text { Category } \\
\text { of the activity }\end{array}$ & $\begin{array}{l}\text { Nature } \\
\text { of the activity }\end{array}$ & $\begin{array}{c}\text { Years } \\
\text { of experience }\end{array}$ \\
\hline $\mathrm{P} 1$ & Coca Cola Company & $\begin{array}{l}\text { North Africa Marketing } \\
\text { Manager }\end{array}$ & $\begin{array}{l}\text { Soft and } \\
\text { energy drinks }\end{array}$ & Announcer & 14 years \\
\hline $\mathrm{P} 2$ & Unik Advertising & Marketing Manager & Advertising & Advertiser & 3 years \\
\hline P3 & Médiacom & General Manager & Advertising & Advertiser & 7 years \\
\hline P4 & $\begin{array}{l}\text { Confidentiality } \\
\text { desired* }\end{array}$ & Multimedia Responsible & $\begin{array}{l}\text { Phone } \\
\text { operator }\end{array}$ & Announcer & 4 years \\
\hline P5 & Indexiweb & Manager & $\begin{array}{l}\text { Web } \\
\text { marketing }\end{array}$ & Advertiser & 3 years \\
\hline P6 & Samsung Electronics & Digital Manager & Electronic & Announcer & 3 years \\
\hline P7 & $\begin{array}{l}\text { Orascom Telecom } \\
\text { Tunisie Tunisiana }\end{array}$ & $\begin{array}{l}\text { Web and } \\
\text { E-Commerce Manager }\end{array}$ & $\begin{array}{l}\text { Phone } \\
\text { operator }\end{array}$ & Announcer & 4 years \\
\hline P8 & $\begin{array}{l}\text { Confidentiality } \\
\text { desired* }\end{array}$ & $\begin{array}{l}\text { Digital Manager } \\
\text { in a multinational } \\
\text { communication agency }\end{array}$ & Advertising & Advertiser & 2 years \\
\hline P9 & Havas Tunisie & Media Managing Director & Advertising & Advertiser & 8 years \\
\hline P10 & $\begin{array}{l}\text { Industries } \\
\text { Alimentaires } \\
\text { de Tunisie (IAT) }\end{array}$ & Brand Manager & $\begin{array}{l}\text { Cheese } \\
\text { industry }\end{array}$ & Announcer & 6 years \\
\hline P11 & Memac Ogilvy Label & Digital Strategist & Advertising & Advertiser & 10 years \\
\hline $\mathrm{P} 12$ & Infochallenge & Manager & $\begin{array}{l}\text { Web } \\
\text { marketing }\end{array}$ & Advertiser & 5 years \\
\hline P13 & Samsung Electronics & HHP Marketing Manager & Electronic & Announcer & 7 years \\
\hline P14 & Topnet & Marketing Manager & $\begin{array}{l}\text { Internet } \\
\text { service } \\
\text { provider }\end{array}$ & Announcer & 7 years \\
\hline P15 & Mindshare & Digital Manager & Advertising & Advertiser & 5 years \\
\hline P16 & $\begin{array}{l}\text { Confidentiality } \\
\text { desired* }\end{array}$ & Brand Manager & $\begin{array}{l}\text { Food } \\
\text { products }\end{array}$ & Announcer & 13 years \\
\hline
\end{tabular}

Confidentiality desired* for informants 4,8 and 16 , who preferred not to disclose information about the name of the company in which they worked.

Source: Authors' research. 
Table 2

Consumers: Description of the interviewees' profile

\begin{tabular}{|c|c|c|c|c|}
\hline Informant & Job description & Gender & Age & Region \\
\hline $\mathrm{C} 1$ & Optician & Female & 28 years & Capital city \\
\hline $\mathrm{C} 2$ & Employee in a company & Female & 40 years & Capital city \\
\hline $\mathrm{C} 3$ & Agronomist & Female & 27 years & Centre \\
\hline $\mathrm{C} 4$ & Biologist & Male & 37 years & South \\
\hline $\mathrm{C} 5$ & Dentist & Male & 34 years & South \\
\hline C6 & Secretary & Female & 42 years & Capital city \\
\hline $\mathrm{C} 7$ & Student & Male & 20 years & North \\
\hline $\mathrm{C} 8$ & Housewife & Female & 49 years & Capital city \\
\hline C9 & Accountant & Male & 51 years & Capital city \\
\hline $\mathrm{C} 10$ & Physiotherapist & Female & 31 years & Capital city \\
\hline $\mathrm{C} 11$ & Restaurant owner & Male & 45 years & South \\
\hline $\mathrm{C} 12$ & Financial officer & Male & 38 years & North \\
\hline $\mathrm{C} 13$ & Nurse & Female & 33 years & Capital city \\
\hline $\mathrm{C} 14$ & Student & Male & 24 years & South \\
\hline $\mathrm{C} 15$ & Banker & Female & 30 years & North \\
\hline $\mathrm{C} 16$ & Retired man & Male & 61 years & Centre \\
\hline $\mathrm{C} 17$ & Employee in a company & Male & 35 years & North \\
\hline $\mathrm{C} 18$ & Primary school teacher & Female & 46 years & South \\
\hline $\mathrm{C} 19$ & Pharmacist & Female & 39 years & Capital city \\
\hline $\mathrm{C} 20$ & Engineer & Male & 53 years & Centre \\
\hline
\end{tabular}

Source: Authors' research.

Two interview scenarios were developed to achieve our research objectives. The interview scenario for professionals focused on (1) the place of social networks in the promotion-mix and buzz campaigns, (2) audiences' perceptions of and reactions to buzz campaigns (exposure to selected stimuli), (3) buzz campaigns and cultural congruency, and (4) alternatives for a successful buzz campaign on social networks. When elaborating the interview scenario for consumers, for the sake of comparability, we tried to keep a certain symmetry, leading to the following themes: (1) consumers' perception of buzz marketing campaigns in Tunisia and elsewhere, (2) perceptions of and reactions to some specific campaigns (exposure to selected stimuli), (3) buzz campaigns and cultural congruency, and (4) suggestions for improved buzz campaign on social networks and practices to avoid.

We selected two stimuli to contrast the opinions of marketing professionals and consumers. The first one is a buzz marketing campaign initiated by a famous national internet service provider. It did not last long as it was removed from the website barely thirty minutes after its publication. It sparked strong reactions and created a bad buzz in the Tunisian society. It represents two men looking at each other in a way that may suggest they are homosexual. This topic has been deemed all the more shocking that homosexuality remains a strong taboo in the traditional ArabMuslim Tunisian society. The second stimulus is an image exposed on the front page of a national newspaper. It shows a soccer player touching the bare chest of his fiancée. It created a huge buzz on Facebook after which the journalists and the manager of the newspaper were arrested. 
The interviews ranged from 25 minutes to 2 hours, depending on respondents' availability. The interviews took place in the form of conversations, with a choice of language given to the respondents (colloquial Arabic, French or a mix of both), to allow them to feel at ease and be more interactive. Interviews were digitally recorded and fully transcribed. We conducted a thematic content analysis. Two major themes are developed below: the central role of cultural congruency in a buzz campaign and success factors of such campaigns on social networks. The excerpts of verbatim drawn from the interviews will be presented in what follows in italics and quotation marks.

\section{CULTURAL CONGRUENCY: A CENTRAL ROLE IN BUZZ CAMPAIGNS}

All our respondents, professionals as well as consumers, declared dedicating an important amount of time to connecting with people through the internet. They described, in different terms, their feeling of belonging to one or several online communities. For this sake, all of them used Facebook, which remains on the top of social networks. Some professionals, to follow this "wave", were also Twitter and LinkedIn members.

"The young communications professionals, bloggers and geeks, working in IT, web development, communication, web marketing, use Twitter but not as much as Facebook social networking. LinkedIn is also sometimes used for professional networking but mostly by geeks and nerds" (P5).

More and more aware of the importance of virtual communities and the emergence of new technologies related to mobile marketing (Wi-Fi, tablets), marketing professionals are attempting to seize this opportunity by getting closer to their members via the social networks.

\subsection{A threatened social compromise?}

All the exposed stimuli and advertisements were perceived as shocking by the interviewees. Indeed, when the line of the campaign was based on taboos, most of consumers and some of the professionals declared to be shocked and to be animated by negative emotions such as irritation, anger or shame.

"I think this is an offensive and provocative campaign that disgusts me to the highest level!!!" (C2).

This echoes previous findings since shockvertising focuses on and seeks to make use of some sensitive issues that concern all or part of the population. Topics may include either issues such as war, pollution, contagious diseases or politics and religion (Arn, 2001).

Our interesting finding is the contrast between professionals and consumers' opinions. Indeed, consumers tend to express several forms of resistance to and rejection of the buzz campaign stimuli, while professionals are more liable to use them and are more at ease with this new marketing trend. This may be explained by the fact that marketers and professionals operating in communication and technology are more westernized, and more undergoing the phenomenon of "acculturation in situ" (Hirschman and Touzani, 2011). This may be explained by their continuous contact with Western stimuli: not only those related to promotion and advertising, but also all the artefacts related to the marketing universe in general. This state of fact transforms them into active acculturation agents introducing and sustaining western representations and mental imagery in a traditional and rather conservative market.

Creating the buzz on social networks by infringing the limits of what is considered as morally correct and socially acceptable brings the question of the boundaries defined by religion and society. The few dissident advertisements in the Tunisian market tried to spark off consumers' reactions by using taboos that could lead to immediate feedback, but that was generally not 
in favour of the promoted brand. Indeed, the use of sex or other taboo topics in advertising is considered as an abuse by the large public. This phenomenon can be explained by companies' will to distinguish themselves from competitors by using nudity and sex oriented lines to provoke by creating shock among the audience. However, they sometimes give rise to a controversy that goes far beyond the mere promotional campaign.

When analyzing the reactions generated by the first stimulus, it is important to underline the significant negative affective states that emerged. This was reflected by the informants' non-verbal micro-expressions revealing shame, embarrassment and discomfort: grimace, frowning, looking down to the ground, body agitation, etc. Beyond these subconscious reactions, our informants clearly stated their uneasiness:

"Two men hugging with a slogan 'It's what I love about you'! I am deeply offended and shaken. They just exhibit this image like this ... it disgusts me!" (C8).

It also appears difficult to distinguish between what originates in values, taboos or religion. The three cultural components seem to blend in a subtle mélange materialized by the prevalent cultural background of the society. As shown, in the following testimony, values, taboos and religious beliefs constitute different materials for a single and unified mould.

"This picture reflecting homosexuality annoys me and touches the sacred principles among which I was raised. This poster inspires a form of deviance and it is completely against our social and religious beliefs" (C9).

This study may offer the premise to draw a social statement revealing the presence of a certain cultural hegemony through a dominant ideology that draws its essence from Islam that retains its exegetical value of the social system. Actually, religion is the cornerstone on which the whole social structure is based. So what is considered as a " $\sin$ " by religion is considered as not socially acceptable. From a sociological point of view, the social compromise seems threatened as through advertising campaigns in social networks, messages can encourage the receiver to deviate from the right path which is in fact the winding road of the morality. Therefore, religiosity contributes to creating a hierarchy of values and thus generates negative reactions if they are violated.

However, a social compromise seems to emerge against the publication of messages or stimuli that may go against these values. Returning to the first visual, homosexuality is firmly denied by the participants. This shows that, in spite of all the exterior signs of westernization, Islam remains an essential anchored reference. Since it strongly condemns this practice, it is considered as a sin and against the established divine order.

"In our society, there are some things we wouldn't accept; an inappropriate message can generate a negative reaction going up to boycotting the product. Homosexuality is a practice against nature and diffusing it among the general public is against our traditions, values and it is especially a sin" (P12).

Publishing this kind of visuals would brandish the spectre of a loss of personal and cultural identity. The receiver of such "intrusive" messages on social networks would be compelled to comply with a pseudo-modern westernized model where freedom sometimes becomes outrageous and offensive and definitely goes against tradition.

"Personally, I am not comfortable with this poster because it is not compatible with our traditions. I would rather see it as an advertising campaign for Benetton which suits most European countries" (C6).

\subsection{The eternal dilemma of nudity}

After exposure to the image (stimulus 2), consumers demonstrated strong reactions of discomfort or even shame. Some of them tried to hide the image; others turned it over, while the others looked away. 
"This nudity and this posture! Honestly, I'm ashamed to see this picture... and confused as well... I would feel uncomfortable and afraid if someone watched me looking at this kind of image..." (C12).

The way the audience receives and manages such campaigns should also be analyzed within the framework contrasting between individualistic and collectivistic societies. As a matter of fact, our participants' testimonies reveal that the other members of the social system's judgements and opinions prevail over individual considerations. Consumers' image as perceived by others is to be considered even if the stimulus does not seem to intrinsically bother the receiver of the message.

"Even if I was alone, this image wouldn't bother me in absolute terms but it could be embarrassing if I was with my colleagues" (C4).

Therefore, decency and reserve prove to be common values inculcated since the early stages of socialization. For this, the dominant rule remains the respect of morality. Consequently, all elements liable to undermine decency and cross its bounds appear as a threat.

"It is true that we have the freedom of expression, but there are limits not to cross.

These limits are materialized by our social principles. Infringing them may affect the person's privacy and private life. Nudity is not tolerated in our context and can but create controversy" (P6).

Making inroads in a forbidden domain resulted in a feeling of aversion among interviewees. This feeling reveals the "mandatory" aspect of social relationships, as individuals seek conformity, often not by conviction but rather in order to warrant the adherence to the social system and to avoid being rejected by the diverse groups of belonging.

"Personally, it doesn't shock me to see these pictures but I have to argue that it is shocking because I belong to a society and I must submit myself to the rules of morality and obey the values setting the socially acceptable" (C7).

\subsection{The sore words}

After exposure to the buzz stimuli, some participants from Southern Tunisia highlighted regional differences materialized through dissimilarities in the way slogans and marketing materials may be perceived. Some respondents have reported that during this campaign of a telephone operator, an actor's line was "Harda" (hole in the budget). An innocent word for the citizens from the North, Central Tunisia and the capital, but containing obscene and vulgar meaning with sexual connotations in Southern Tunisia! Consequence: many felt offended.

"I do not understand how they could diffuse that. It's totally disrespectful ... It sounds insulting to me. I thought to change the telephone operator. I called the Customer Service to complain and show my disappointment and indignation at this unfortunate offence" (C11).

Returning to this point of view with the professional working for this company, he said that the number of claims due to this advertising had reached more than 3,500 calls. This inadvertent error in the choice of words and the ignorance of their meaning varying from one region to another confirm the importance of considering each term and using it in accordance with the morals and traditions of each region.

Accordingly, the words used in commercials must be decent and the choice of words must avoid misinterpretations and innuendos. The weight of words is of crucial importance not to hit people or subcultures.

"We must also pay attention to the words used with different meanings between the regions and adopt a more refined language in slogans, avoiding teen jargon that seems vulgar to adults" (P2). 


\section{DARING, YES ... BUT...}

It should be noted that some participants tend to set themselves up as censors of "unconventional" advertising. "I don't think it can be published. Me I go for less naked with a touch of humour" (C5).

However, it is possible to detect a certain idiosyncrasy among respondents, which clearly denotes an obvious change of mentality due to the cultural integration with young fans of social networks, tolerating stimuli that can create a controversy among adults.

"I'm used to seeing this kind of advertising on social networks that I check daily for hours and must be open-minded to accept different messages. Compared to my father, who is against the use of the internet, he would never accept this kind of message" (C14).

In this environment, a red line is crucial. However, advertisers do not hesitate to engage in sensitive and offensive messages just to be pioneers in the market.

One of the main goals of advertisers is making the ad discernible, but the famous idea saying "sex sells" does not apply in all societies for ethical considerations.

"Advertisers are not stupid. There is no magic method for a successful buzz campaign on social networks. On the other hand, everything considered as offensive and outrageous is to be avoided. We have to keep in mind that our target is sensitive about the traditions, rituals, symbols and cultural values, and crossing the limits of the socially acceptable could be inconvenient for the brand or for the advertiser. For us, as a multinational we have rules to follow up and a marketing guideline to respect in order to preserve our image worldwide. No deviation is permitted" (P1).

Concerning the professionals, we feel an aspiration to engage in "daring" advertising but there are some obstacles posed by the head office for multinationals following the rules, or by advertisers censoring themselves by repressing flooding ideas. This adds to the limits set by the hearing and underlying socio-religious system in which the advertiser belongs.

"We all would like to be able to let our imagination run without reins and let the inspiration guide us without any constraint. At the present time, the announcers do not dare go on a slippery slope by attacking the cultural side as they may be scared by the potential backlash against their product/service. The advertisers get in a process of self-censorship sometimes even before the presentation of the idea or the customer insight. The solution is to avoid any excess and to proceed in several stages. At present, we cannot shock directly. Time should be taken to let mentalities evolve: when they are ready to accept provocation, it will be possible to move to the next stage." (P9)

"As an advertiser, I'd like to line up with the limits of what is allowed and accepted. But I think we must dare... but finding the right mix. It's like an equation which should, before being fixed, make certain conditions and limitations that would give creativity a different scale. Creativity is the preferred solution because it would draw unusual and original ideas without falling into profane or shockvertising" (P8).

Although social networks are a means of interpersonal communication, an escalation of provocative advertising is to be considered carefully since these ads can spread very quickly through viral marketing and the internet can serve as a pre-test for the TV part of the campaign.

On the other hand, consumers tend to reject this kind of advertising claiming that there was no antecedent before (only a few failed attempts) and there would be no reason to change the principles of this medium even though the channel is social networks. They propose to use other levers like humour and creativity. Congruency between the cultural values in advertising and those of the target audience is recommended.

By following this principle, it is possible to tackle taboo subjects such as homosexuality and nudity without offending the receiver of the advertisement. Innovation in advertising makes all 
topics reachable. In doing so, a wise use of imagination without falling into the excess represents a loophole for the pitfalls that may be encountered by the advertisers in the post-buzz campaign on social networks.

"For an advertiser, there is a code of ethics to follow, but it may not necessarily express creativity defying the rules of morality and what to do about the product. In Tunisia, it remains very special and very dangerous for a brand to tackle the sacred values of the message receiver. We must dare yes but everything is relative. We must find the right formula not to fall into the irreverent" (P9).

\section{DISCUSSION AND MANAGERIAL IMPLICATIONS}

Many advertisers are committed to buzz marketing campaigns, trying to increase their visibility and improve their brand image. This approach is ambitious but still quite dangerous because of the restrictions related to the congruency of the advertising messages with the audience's values. It is a must to identify the central role of this congruency in the assimilation of messages even in their acceptance or rejection.

We conducted a qualitative survey through 36 individual interviews with 16 professionals and 20 consumers. This study aims at pointing to both teaching and research purposes. Indeed, at the end of this work, two main results arise and are discussed below.

First of all, in a buzz campaign, it is wise to seek a balance between emotions aroused among the target, its cultural values and the "socially acceptable". Tact and care are needed when using sexuality and nudity, especially in an Arab-Muslim setting strongly influenced by religion present every day in its social system. These controversial issues can affect the values and touch the taboos. A fair balance between "daring" and conventional seems to be a necessity.

Secondly, the weight of words and the level of decency of the terms used in the advertisement are of great importance and could be decisive in the success of a buzz campaign. For this purpose, predicting the risks of misinterpretation in advance can help avoiding a bad buzz.

These two results provide a first insight into the success factors of a buzz marketing campaign focusing on the cultural aspect through highlighting congruency between the advertising message and the local culture of its receiver. Moreover, combining both professionals' and consumers' points of view has helped to better understand the role of this congruency under two directions: the one of the advertiser and the other of the receiver. Because of the scarcity of publications about buzz and the consideration of the cultural component, this research provides some preliminary answers on the factors of a successful buzz campaign generated by a business.

However, this research paper does not include factors that can affect companies' intention to choose buzz marketing campaigns' thematics. The use of shocking buzz campaigns is sometimes justified by the importance of brand awareness, even when the buzz campaign is a negative one. Brand awareness can be a factor to include in future research papers. To assure a better sample heterogeneity, stimuli may be selected for companies with various levels of brand awareness. We also have asked Tunisian consumers about buzz campaigns to better know about cultural factors that can affect their perceptions. It can be promising to focus on two different cultures by asking consumers about common buzz marketing campaigns, such as those of global companies, and try, via a cross-cultural study, to explore cultural factors that can affect consumers' perceptions of shocking buzz campaigns. A research model may be proposed and tested in different cultural environments. 


\section{References}

Abernethy, A. and Franke, G. (1996) "The Information Content of Advertising: A Meta-Analysis", Journal of Advertising, 25(2), pp. 1-17.

Al-Makaty, S., Tubergen, G., Whitlow, S. and Doyd, D. (1996) “Attitudes Toward Advertising in Islam”, Journal of Advertising Research, 36, May/June, pp. 16-26.

Al-Olayan, F. and Karande, K. (2000) "A content analysis of magazine advertisements from the United States and the Arab world", Journal of Advertising, XXIX, 3, pp. 69-82.

Alston, M. and Bowles, W. (2003) Research for Social Workers: An Introduction to Methods, $2^{\text {nd }}$ edition, London: Routledge.

Arn, R. (2001) La publicité choquante: Vers une nouvelle dimension du droit de la concurrence déloyale? Etude des droits allemand, finlandais, norvégien, français et suisse, Bâle: Helbing \& Lichtenhahn.

Ashley, C. and Tuten, T. (2015) "Creative strategies in social media marketing: An exploratory study of branded social content and consumer engagement”, Psychology \& Marketing, 32(1), pp. 15-27.

Aymé, A., Gastal, A. and Gastal, M. (2011) Créateurs d'entreprise, optimisez votre développement grâce au web: Concevez une stratégie internet efficace et rentable, Dunod.

Ben Yahia, K., Touiti, S. and Touzani, M. (2012) Intégration du buzz dans le mix communicationnel: entre cohérence et dangers, 6th International Research Days on Marketing Communications, March 29-30, Nancy, France.

Burcher, N. (2012) Paid, Owned, Earned: Maximising Marketing Returns in a Socially Connected World, Kogan Page.

Buzzell, R. (1986) “Can You Standardize Multinational Marketing?”, Harvard Business Review, 46(6), pp. 102-113.

Cai, Y. and Shannon, R. (2012) "Personal values and mall shopping behaviour: The mediating role of intention among Chinese consumers", International Journal of Retail \& Distribution Management, 40(4), pp. 290-318.

Cazeneuve, J. (1971) Sociologie du rite, PUF, Collection SUP.

Chatterjee, S.R. and Tata, R. (1998) "Convergence and divergence of ethical values across nations: A framework for managerial action", Journal of Human Values, 4(1), pp. 5-23.

Cleveland, M., Laroche, M. and Hallab, R. (2011) "Globalization, culture, religion, and values: Comparing consumption patterns of Lebanese Muslims and Christians", Journal of Business Research, in press.

Connor, P.E. and Becker, B.W. (2003) "Personal value systems and decision-making styles of public managers", Public Personnel Management, 32(1), pp. 155-80.

Dahl, D.W., Frankenberger, K. and Manchanda, R.V. (2003) "Does it pay to shock? Reactions to shocking and nonshocking advertising content among university students", Journal of Advertising Research, 43(3), pp. 268-280.

Delner, N. (1994) "Religious contrasts in consumer decision behavior patterns: Their dimensions and marketing implications", European Journal of Marketing, 28(5), pp. 36-53.

Durgee, J.F., Colarelli O'Connor, G. and Veryzer, R.W. (1996) “Translating Values Into Product Wants”, Journal of Advertising Research, 36.

Durkheim, E. (1915) Les formes élémentaires de la vie religieuse, $5^{\text {th }}$ edition, Quadrige, Presses Universitaires de France.

Durvasula, S., Lysonski, S. and Madhavi, A.D. (2011) "Beyond service attributes: do personal values matter?", Journal of Services Marketing, 25(1), pp. 33-46.

Earle, W.B. (1986) "The social context of social comparison: Reality versus reassurance", Personality and Social Psychology Bulletin, 12(2), pp. 159-168.

England, G.W and Lee, R. (1974) "The relationship between managerial values and managerial success in the United States, Japan, India, and Australia", Journal of Applied Psychology, 59(4), pp. 411-419.

Ersig, M.C. (2001) Understanding culture as communication: An exploratory study of US tv commercials, Master's Thesis, California State University.

Fam, K.S., Waller, D.S. and Zafer Erdogan, B. (2004) "The influence of religion on attitudes towards the advertising of controversial products", European Journal of Marketing, 38(5/6), pp. 537-555.

Feather, N.T. (1975) Values in education and society, New York: Free Press.

Flick, U. (2009) An Introduction to Qualitative Research, $4^{\text {th }}$ edition, London: Sage Publication.

Fournout, V., Le Friant, G. and Hazera, J.M. (2012) Emailing, newsletter, sms, réseaux sociaux: Guide complet du marketing direct en ligne, Maxima.

Freud, S. (1912) Totem et Tabou, Paris: Gallimard, 1993.

Gallissot, L. (1994) "The Cultural significance of advertising: A general framework for the cultural analysis of the advertising industry in Europe", International Sociology, 9, pp. 13-28.

Garcia, R. (2010) La publicité choc: la notion d'images choquantes dans les affiches publicitaires, une interprétation multiple, mémoire de fin d'études, IUT Robert Schuman.

Harris, G. and Attour, S. (2003) "The international advertising practices of multinational companies: A content analysis study", European Journal of Marketing, 37(1/2), pp. 154-168. 
Harris, G. (1984) "The Globalization of Advertising”, International Journal of Advertising, 3(3), pp. $223-34$.

Heywood, J.L. (2002) "The cognitive and emotional components of behavior norms in outdoor recreation", Leisure Science, 24(3/4), pp. 271-281.

Hirschman, E.C. and Touzani, M. (2011) "Consumer acculturation in situ: the continuing legacy of French colonization in North Africa", in: Sandikci, O., Rice, G., Handbook of Islamic Marketing (pp. 114-128).

Holton, J.A. (2010) “The Coding Process and Its Challenges”, The Grounded Theory Review, 9(1), pp. 21-40.

Hong, J.A., Muderrisoglu, A. and Zinkhan, G. (1987) “Cultural differences and advertising expression: A comparative content analysis of Japanese and us magazine advertising", Journal of Advertising, 6(1), pp. 55-68.

Kilicbay, B. and Binark, M. (2002) "Islam and the politics of lifestyle: Fashion for veiling in contemporary turkey consumer culture", European Journal of Communication, 17(4), pp. 495-511.

Kimmel, A.J. (2014) "Connecting with consumers via live buzz marketing: public perceptions and the role of ethical ideology”, Business Ethics: A European Review, 24(2), pp. 205-220.

Koubaa, Y., Ulvoas, G. and Chew, P. (2011) "The dual impact of traditional and national cultural values on expatriate ethnic groups' attitudes and willingness to buy", Asia Pacific Journal of Marketing and Logistics, 23(5), pp. 626-640.

Kozinets, R.V., De Valck, K., Wojnicki, A.C. and Wilner, S.J.S. (2010) "Networked narratives: understanding wordof-mouth marketing in online communities", Journal of Marketing, 74, March, pp. 71-89.

Lambek, M. (1992) "Taboo as cultural practice among Malagasy speakers", Journal of the Royal Anthropological Institute, 27(2), pp. 245-266.

Liessem, C. (2015) The Global-Local Paradox in International Advertising. Can Marketing Really Be International?, GRIN Verlag.

Longhofer, J., Floersch, J. and Hoy, J. (2012) Qualitative Methods for Practice Research, Oxford University Press.

Luqmani, M., Yavas, U. and Quraeshi, Z. (1989) “Advertising in Saudi Arabia: Content and regulation”, International Marketing Review, 31(3), pp. 35-39.

Marques, J.M. and Paez, D. (1994) "The black sheep effect: social categorization, rejection of in group deviates, and perception of group variability”, European Review of Social Psychology, 5(2), pp. 37-68.

McCracken, G. (1986) "Culture and consumption: A theoretical account of the structure and movement of the cultural meaning of consumer goods", Journal of Consumer Research, 13(1), pp. 71-84.

Moriarty, S., Mitchell, N.D., Wells, W.D., Crawford, R., Brennan, L. and Spence-Stone, R. (2014) Advertising: Principles and Practice, $3^{\text {rd }}$ edition, Pearson.

Mueller, B. (1987) "Reflections of Culture: An Analysis of Japanese and American Advertising Appeals", Journal of Advertising Research, 27(3), pp. 51-59.

Oosterwijk, L. and Loeffen, A. (2005) How to use buzz marketing effectively: A new marketing phenomenon explained and made practical, Master Thesis, School of Business, Mälardalen University, Sweden.

Opsomer, P. and Bizien, G. (2008) Les nouvelles tendances du marketing: Le buzz marketing quand les consommateurs deviennent des 'consomm 'acteurs', Rapport de l'ESC Toulouse.

Patton, M.Q. (2002) Qualitative Research and Evaluation Methods, Sage Publications.

Pollay, R.W. (1983) "Measuring the Cultural Values Manifest in Advertising", in: Leigh, J. and Martin, C. (Eds.), Current Issues and Research in Advertising (pp. 72-92), Ann Arbor, MI: University of Michigan Graduate School of Business Division of Research.

Pollay, R.W. (1986) “The Distorted Mirror: Reflections on the Unintended Consequences of Advertising”, Journal of Marketing, 50, April, pp. 18-36.

Proulx, S., Millette, M. and Heaton, L. (2012) Médias sociaux: Enjeux pour la communication, Presses de l'Université du Québec.

Rokeach, M. (1973) The nature of human values, New York: Free Press.

Rosen, E. (2001) The anatomy of buzz: How to create word of mouth marketing, London: Harper Collins Business.

Sabri, O. and Obermillerb, C. (2012) "Consumer perception of taboo in ads", Journal of Business Research, 65(6), pp. 869-873.

Sabri, O. (2015) “Does Viral Communication Context Increase the Harmfulness of Controversial Taboo Advertising?", Journal of Business Ethics, Springer Verlag, p. 15.

Schatcher S. (1961) "Deviation, rejection and communication", Journal of Abnormal and Social Psychology, 46, pp. 190-207.

Skorupa, P. (2014) "Shocking contents in social and commercial advertising", Creativity Studies, 7(2), pp. 69-81.

Salzman, M., Matathia, I. and O’Reilly, A. (2003) Buzz... Harness the Power of Influence and Create Demand, New Jersey: John Wiley \& Sons Inc.

Schur, E.M. (1971) Labelling deviant behavior: its sociological implications, New York: Harper and Row.

Severn, J., Belch, G.E. and Belch, M.A. (1990) "The Effects of sexual and non-sexual advertising appeals and information level on cognitive processing and communication effectiveness", Journal of Advertising, 19(1), pp. 14-22. 
Snyder, L.B., Willenborg, B. and Watt, J. (1991) “Advertising and Cross-Cultural Convergence in Europe”, European Journal of Communication, 6(4), pp. 441-468.

Stambouli, K. and Briones, E. (2002) Buzz marketing les stratégies du Bouche à oreille, Paris: Éditions d'Organisation. Strauss, A. and Corbin, J. (1990) Basics of qualitative research: Grounded theory procedures and techniques, Newbury Park, CA: Sage.

Sternthal, B. and Craig. C.S. (1973) "Humor in advertising”, Journal of Marketing, 37(4), pp. 12-18.

Tansey, R., Hyman, M. and Zinkhan, G. (1990) "Cultural Themes in Brazilian and US Auto Ads: A Cross Cultural Comparison”, Journal of Advertising, 19(2), pp. 30-39.

Tse, D.K., Belk, R.W. and Zhou, N., (1989) "Becoming a Consumer Society: A Longitudinal and Cross-Cultural Content Analysis of Print Ads from Hong Kong, the People's Republic of China and Taiwan”, Journal of Consumer Research, 15(4), pp. 457-472.

Van Dyke, A.W., (1980) "Stop Killing us with Kindness”, Journal of Marketing, 40(3), p. 90.

Walter, T. (1991) “Modern Death: taboo or not taboo?", Sociology, 25(2), pp. 293-310.

Webster, H. (1942) Le tabou: une étude sociologique, Paris: Payot.

Zhang, Y. and Gelb, B.D. (1996) "Matching advertising appeals to culture: The influence of product's use conditions", Journal of Advertising, XXV, 3, pp. 29-46. 